\title{
Response to correspondence from Koerner and colleagues concerning our paper entitled: The effect of diluting povidone- iodine on bacterial growth associated with speech
}

\author{
Sivashanth Gnanasekaran * (D, Sophie Rogers, Sanj Wickremasinghe and Sukhpal S. Sandhu
}

\begin{abstract}
Clinicians adopt varying strategies for antisepsis with $\mathrm{Pl}$, which to this day remains efficient, economical and effective. Clinicians should prudently consider effective PI application, and we thank Koerner and Grzybowski for encouraging debate and raising the profile of this issue.
\end{abstract}

Keywords: Anti-VEGF, Endophthalmitis, Intravitreal injection, Povidone-iodine, Pre-injection antisepsis

\section{Main text}

We thank Koerner and Grzybowski [1] for their comments regarding the study on the effect of diluting povidone-iodine (PI) on bacterial growth associated with speech [2]. We agree that there are no standardized reliable ways to simulate the ocular surface to analyse this in vitro, and stress that the emphasis of this study design is to add to the evidence base. This study demonstrated the differences in PI dilution and significant bacterial culture growth with bacterial droplet dispersal associated with speech. Whilst there is evidence to suggest lower doses of PI is effective [3], we note that other evidence suggest that these lower doses require several applications [4]. Clinicians adopt varying strategies for antisepsis with PI, which to this day remains efficient, economical and effective [5]. Clinicians should prudently

This reply refers to the comment available at https://doi.org/10.1186/s12886020-1313-9.

* Correspondence: Sivashanth.Gnanasekaran@wh.org.au

Centre For Eye Research Australia, The Royal Victorian Eye and Ear Hospital, University of Melbourne, 32 Gisborne Street, East Melbourne, Victoria 3002, Australia

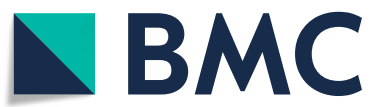

consider effective PI application, and we again thank Koerner and Grzybowski for encouraging debate and raising the profile of this issue.

\section{Abbreviation \\ PI: poviodone-iodine \\ Acknowledgements \\ Not applicable.}

\section{Authors' contributions}

SG contributed to the study design, data collection and manuscript writing. SR and SW contributed to data analysis, data interpretation and manuscript writing. SS contributed to data analysis, data interpretation, manuscript writing and co-ordinated the study. The author(s) read and approved the final manuscript.

\section{Funding}

The Centre for Eye Research Australia receives operational infrastructure support from the Victorian Government. The funder had no role in our study.

\section{Availability of data and materials}

The dataset used and/or analysed during the current study are available from the corresponding author on reasonable request. All data generated or analysed during this study are included in this published article.

(0) The Author(s). 2020 Open Access This article is licensed under a Creative Commons Attribution 4.0 International License, which permits use, sharing, adaptation, distribution and reproduction in any medium or format, as long as you give appropriate credit to the original author(s) and the source, provide a link to the Creative Commons licence, and indicate if changes were made. The images or other third party material in this article are included in the article's Creative Commons licence, unless indicated otherwise in a credit line to the material. If material is not included in the article's Creative Commons licence and your intended use is not permitted by statutory regulation or exceeds the permitted use, you will need to obtain permission directly from the copyright holder. To view a copy of this licence, visit http://creativecommons.org/licenses/by/4.0/ The Creative Commons Public Domain Dedication waiver (http://creativecommons.org/publicdomain/zero/1.0/) applies to the data made available in this article, unless otherwise stated in a credit line to the data. 


\section{Ethics approval and consent to participate}

This study was originally approved by The Royal Victorian Eye and Ear

Hospital's human research ethics committee and involved a series of healthy participants. Written informed consent was obtained from all study participants.

\section{Consent for publication}

Not applicable.

\section{Competing interests}

The authors declare that they have no competing interests.

Received: 27 April 2020 Accepted: 5 August 2020

Published online: 12 August 2020

\section{References}

1. Koerner J, Grzybowski A. Povidone-iodine pharmacokinetics and study design. BMC Ophthalmol. 2020;20(1):29.

2. Gnanasekaran S, Rogers S, Wickremasinghe S, Sandhu SS. The effect of diluting povidone-iodine on bacterial growth associated with speech. BMC Ophthalmol. 2019;19(1):62.

3. Koerner JC, George MJ, Kissam EA, Rosco MG. Povidone-iodine concentration and in vitro killing time of bacterial corneal ulcer isolates. Digit J Ophthalmol. 2018;24(4):24-6.

4. Silas MR, Schroeder RM, Thomson RB, Myers WG. Optimizing the antisepsis protocol: effectiveness of 3 povidone-iodine 1.0\% applications versus a single application of povidone-iodine 5.0. J Cataract Refract Surg. 2017;43(3):400-4.

5. Grzybowski A, Kanclerz P, Myers WG. The use of povidone-iodine in ophthalmology. Curr Opin Ophthalmol. 2018;29(1):19-32.

\section{Publisher's Note}

Springer Nature remains neutral with regard to jurisdictional claims in published maps and institutional affiliations.

- fast, convenient online submission

- thorough peer review by experienced researchers in your field

- rapid publication on acceptance

- support for research data, including large and complex data types

- gold Open Access which fosters wider collaboration and increased citations

- maximum visibility for your research: over $100 \mathrm{M}$ website views per year

At BMC, research is always in progress. 